\title{
In the Wake of God's Fire: Transforming Charisma and Charismata in the Reconstruction of a Local Church
}

\section{Jane Skjoldli}

"We're pretty fresh out of a crisis a few years back," began Matthew. "People think we are Living Word. We are not. That church is dead. It doesn't exist anymore. We have the same address and the same building, but a lot has changed. The name is just one of those things. We still believe in the same God, but the leadership has been replaced completely. Only one of those who used to be involved in leadership still is."

Matthew is one of the respondents in an ethnographic study on a local Charismatic church in Bergen, Norway, carried out in the summer of 2013. The church was formerly known as "Living Word" (Levende Ord), and to some extent still is, despite being renamed "The Credo Church" (Credokirken) in 2009. In the quote above, Matthew points out similarities and differences between the two. To the extent that Living Word still exists, it is in the form of the Credo Church: Both churches believe in the same God and reside in the same building, he says. Nevertheless, much has changed. Among the changes he chose to draw attention to were those made to the leadership.

J. Skjoldli $(\bowtie)$

University of Bergen, Bergen, Norway

(C) The Author(s) 2018

J. Moberg, J. Skjoldli (eds.), Charismatic Christianity in Finland, Norway, and Sweden, Palgrave Studies in New Religions and Alternative Spiritualities, https://doi.org/10.1007/978-3-319-69614-0_4 
Through participant observation at Sunday services and other events; formal interviews and informal conversations over coffee; post-service Sunday dinners; small group meetings; and by reading news material, promotional material, and master theses on the church (Bryne 2007; Steinhovden 2006), I learned that the Credo Church's leadership involves new practices as well as new personnel, differences in structure as well as ideals. At Living Word, authority was primarily ascribed to the founder and senior pastor. Leadership at the Credo Church is also headed by a senior pastor, but it also involves a management team and a board with whom he collaborates. Moreover, leaders are accountable to a set of statutes and the church's general assembly, which includes all registered members, was established and is empowered to change church practice and policy. In Weberian terms, authority has shifted from a deeply charismatic form to a more rationalized form - a process commonly referred to as the routinization of charisma (Weber 1947, 363), which informs the analysis below. As terminological irony would have it, Weberian charismatic authority among Charismatics is often tied to the very practices they associate with the term Weber recruited for his conceptualization of the term, namely the charismata - the gifts and manifestations of the Holy Spirit. Living Word was no exception. Typically, routinization of charisma is regarded as a necessity following the loss of a charismatic leader. Sometimes, however, a leader's loss of charismatic authority precedes the loss of the leader himself (see e.g. Weber 1947, 359-60; Yukl 1999, 297). This appears to have been the case at Living Word. When members discontinued attributing charismatic authority to the leader, a group within the congregation created the previously nonexistent means for deposing the leader. The process began due to disagreement over leadership style, which was perceived as too authoritarian, even to the point of autocracy (Hellesund 2006). Furthermore, allocation of church funds had come under scrutiny from local authorities (Wiederstrøm 2006). As the discussion will show, however, gifts and manifestations were themselves important pieces of the puzzle regarding how charismatic authority diminished, but also how it was reconstructed.

What can the members interviewed for this study teach us about gifts and manifestations on the one hand, and the construction of charismatic authority on the other? This chapter examines that question mainly on the basis of semi-structured interviews with members of the Credo Church, who were also members of Living Word. The exploration is divided into three main sections: The first discusses the two concepts of charisma relevant to this study. Applying a Weberian 
perspective, the second section examines authority transformations as part of the congregation's reconstruction process. The third section analyzes respondents' approaches to gifts and manifestations in light of the discussion on authority transformations.

\section{Making SENSE OF CHARISMA}

For the purposes of the following analysis, two main concepts of charisma need to be addressed. The first is the Weberian concept of charisma-a sociological concept that constitutes an essential component of Weber's theory of the three sources of legitimate authority. Charisma in this respect underpins charismatic forms of authority, which are considered "inherently unstable and temporary" (Weber 1947, 71), as opposed to traditional and rational forms.

The second concept is perhaps best described as a cluster of Christian notions connected to the emic term charisma. According to Barclay M. Newman, Jr.'s Greek-English dictionary of the New Testament, charisma (plural: charismata) denotes a "gift as an expression of divine grace," or "a special manifestation of the divine presence, activity, power or glory" (1993, 197, italics added). Both are reflected in Norwegian Charismatic terms, where the word commonly used for charismata is "gifts of grace" (nådegaver) and "manifestations of the Spirit" (Andsmanifestasjoner). The interviews were all conducted in Norwegian, and the transcript translations into English are my own. In order for the text to stay as close as possible to the original Norwegian responses, I have chosen to apply "gifts of grace" rather than the English idiomatic term spiritual gifts, which is more closely related to the Greek term anyway (see also Poloma 1997, 259).

What experiences and practices constitute the emic categories corresponding to the terms "gifts of grace" and "manifestations of the Spirit"? The question is rarely asked in Pentecostal studies, despite acknowledgment that the answers are subject to variation among practitioners (Skjoldli 2014,95 ). Furthermore, the terms are sometimes used interchangeably, but may also refer to separate categories. An illustrative example is how elements ascribed to the "gifts" category tend to be referred to simply as "the gifts," often followed by just a few examples, implying that their boundaries are self-evident (e.g., Anderson 2015, 7-8; Coleman 2000, 21; Inbody 2015, 1; Poloma 1997, 259; Robbins 2004, 117; Singleton 2011, 384). The neglect of nuance has been acknowledged (Anderson 2010, 20) but, given the continued centrality of gifts and manifestations to defining 
Pentecostal and Charismatic forms of Christianity (Anderson 2010, 2014, 6; di Giacomo 2009, 15; Robbins 2004, 117), the absence of problematization presents a paradox. When treated as separate categories, "gifts" are often catalogued by referring to 1 Corinthians: 12 as an index that includes glossolalia, interpretation of glossolalia, prophecy, healing, miracles, Words of Knowledge, Words of Wisdom, a special form of faith, and discernment of spirits (see also Anderson 2014, 19). By contrast, no Bible passage is treated similarly as an index for "manifestations." Instead, the limits of the latter category have often been contested. Examples habitually associated with the category count the widespread phenomenon of "falling in the Spirit" ("being slain in the Spirit" is not used in Norwegian); uncontrollable laughter, crying, and trembling; some kinds of exorcism; and animal imitation (Skjoldli 2014, 81; Poloma and Hoelter 1998, 261). While not central here, it should be noted that the respondents featuring in this study treat the categories in more complicated ways.

"Gifts" and "manifestations" also have important features in common: first, their origin and distribution is generally attributed to God. Second, when elaborated upon, gifts and manifestations are usually legitimized by recourse to biblical texts. Charismatics and non-Charismatics tend to differ on whether authentic gifts of grace are currently operational or even of interest (e.g., Anderson 2014, 20-39), thus contributing to disagreements between them. Among Charismatics themselves, disputes over manifestations have displayed the potential to create controversy, whilst providing paths to innovation as well as division. Such disputes have led to the establishment of new congregations, some of which have grown into new movements (Skjoldli 2014, 94). In short, understandings of gifts and manifestations are subject to dynamics of negotiation through the enacted theology of how they are and are not practiced. With these nuances in mind, we turn to authority transformations as part of the reconstruction of the Credo Church's congregation, paying particular attention to the gift of prophecy.

\section{Prophecy: A Double-edged Sword}

Living Word was originally founded as "Word of Life Bergen" (Livets Ord Bergen) by the married couple Enevald and Olga Flăten in 1992; its name bears testimony to the spread of "Word of Life" congregations and other Faith communities in Nordic countries during the 1980s and 1990s. The church was renamed "Living Word Bible Centre" (Levende Ord Bibelsenter) in 1994 in order to avoid confusion with Ulf Ekman's church 
at Uppsala, Sweden (Credokirken 2014), where Enevald Flåten attended Bible college twice. The second time, he was already the founder and senior pastor of the "Jæren Christian Center" (Jæren Kristne Senter) in the county of Rogaland, in southwestern Norway. At the Bible college, Flăten received a new vision from God. It is helpful to consider Flåten's own account:

One day, I lay between the rows of seats at the Bible college. Then God's Spirit came. He touched my heart and he spoke to me, saying: "Write [this] down." And I wrote down the entire vision for the whole [process of] starting a church in Bergen. I wrote: It will be a base for mission, evangelizing, and church planting. [...] It will be a place for teaching, where you will teach the people in all of God's counsel. It will be a place where God's love will be poured out. It will be a place of deliverance, healing, and restoration, and a prophetic voice to the nation. (Kanal 10 Norge 2014)

Flåten's story takes the form of a testimony that involves a revelation from God. Reference to prophecy is made both implicitly and explicitlyimplicitly by way of reporting direct communication with God, explicitly regarding the mission and future of the church. Narratives that involve direct speech from God and appoint someone for a mission, giving them a vision for the future, and the conviction required to fulfill them, are all native to Charismatic discourse. George D. Chryssides and Margaret Z. Wilkins have identified such narratives as foundation myths. When applied to this case, the narrative can be seen to define the nature of Flăten's leadership as sanctioned by God and revealed through prophecy (Chryssides and Wilkins 2006, 35-36). The narrative had the potential to imbue Flåten with Weberian charisma. These very elements can be detected in one congregant's account of the service at Jæren Christian Center, where Flåten shared his message:

There was one service during a conference where Enevald said he had something to share with us. He told [us] that he had received [a message] from God that he should start a church in Bergen. He had received a word, that "Bergen is an important city to God." There were many who approved of that idea. At the service, there were many who said they were going to move to Bergen and start the church. Many left [for Bergen] at that time.

Having proclaimed his new vision to the congregation, Flăten and a group of families from Jæren relocated to Bergen to establish the new church. We may note the openness with which congregants reportedly responded to the 
newly revealed vision. In the years to come, the proclamation that "Bergen is an important city to God" turned into a founding vision for the congregation, but also remained an individual vocation for Flăten (Opheim 2012).

My respondents disagreed on how prevalent prophecies had been at Living Word. While another respondent, Paula, reported that prophecies had been far more common at Living Word than in the present church, Matthew stated that "there were few prophecies, really." He was concerned with the function of prophecy in relation to conversion, explaining how, "in the Bible, it says that, if somebody brings prophetic words, they [non-Christians] would be busted!" Matthew was referring to 1 Corinthians: 14, 24-25, where Paul the apostle instructs his readers that "[i]f everybody speaks prophetically, and an unbeliever or an uninformed [person] comes in, he will be convinced by everybody, he will be convicted by everybody. And so, everything concealed in his heart is revealed. And then he will fall down on his face, and he will worship God and testify that God is truly among you" (Bibelen: Guds Ord 1997, author's translation). ${ }^{1}$ In this interview, Matthew connected prophecy primarily to conversion, which challenges a conceptualization of prophecy as simply "prediction and revelation" (Anderson 2014, 20).

Paula had considered herself a Christian all her life, but recounted one specific experience she described as prophetic, motivating her to commit to her faith and remain in the congregation:

Paula: I know that something specific happened at the first service I attended here [at Living Word]. Something new happened then, where I was [allowed] to know Jesus. The pastor [Flåten] was walking around in the hall and said, "I feel so strongly that there is a [young person] here." [And then] he was able to give an account of my life prophetically. He had very concrete [messages] from God. But I did not dare to make myself known. I was terrified, because I had never experienced that kind [of thing] before-that you prophesy in that way. But I felt inside that something really loosened [up]. I knew it was [for] me.

Jane: That must have been an incredible experience.

Paula: It was. It was [a] very powerful [experience] for me. There were a lot of people around as well. You felt special, like, "Wow, God cares about me." There were lots of things he [the pastor] said, too, "God sees you and has seen you-what you have been through." 
From Paula's story, we understand that, as the pastor spoke, she identified with the "you" addressed in the message given; to her, it was a prophetic account of her life. Through Paula's description of the experience as an encounter with Jesus, and of the message as prophetic, we learn how the pastor could function as the human mediator of that message. This made her feel acknowledged and singled out from the larger group of attendees, and ultimately influenced her to commit to her faith. She felt that she was important to God, important enough that God chose to convey a message to her rather than another. In this story, God emerges as a nurturer, a caretaker who acknowledges her personal struggles, and fulfills her need to feel recognized, and to have her pain acknowledged.

By 2004, Living Word had risen to national prominence and become Norway's largest independent church (Selbekk 2012,2). That year, Living Word had 2549 registered members and formed a nucleus in a loose network of smaller churches (Gjestad 2012, 17). Living Word produced its own monthly magazine called "Flaming Fire" (Flammende Ild), published books at Levende Ord Forlag, and broadcast weekly services on the state television channel NRK2's frequency. ${ }^{2}$ The church also ran a kindergarten, a primary school, a secondary school, a Bible college, various social activities, an international missionary network, and weekly and bi-weekly Bible study groups. Living Word was a congregation with megachurch ambitions that, hypothetically, could encapsulate one's entire life.

Meanwhile, Flåten's statements on God, gender, Islam, and homosexuality gained him attention in the public eye, which probably also served to increase public awareness of the church (Lie 2011, 516). In 2003, a documentary criticizing church members for organizing events that featured glossolalia at the primary school aired on national television (NRK 2003). The following year, controversial politician and former leader of the rightwing Progress Party Carl I. Hagen visited the church, trying to gain voters by making statements expressing support for the state of Israel and opposition to Islam (Aftenposten 2004; Honningsøy 2011). In 2005, politicians from other parties also visited (Hamre 2005). The years 2004-2005 were likely Living Word's peak period in terms of political influence, as well as member numbers and international outreach (Algrøy 2012b; Credokirken 2014). Living Word had grown into a bright feather of the Faith Movement's Nordic wing.

Discontent was growing within, however. Former members reported that channels by means of which members could express criticism and dissatisfaction, or ask questions, were lacking. As one former member put it, "if anyone chose to leave the congregation, they would risk being libeled 
from the pulpit. No one could leave retaining their honor, and many chose to stay because of that - for fear of "falling outside the blessing"" (Almelid $2012 \mathrm{~b}, 18$ ). Toward the end of 2005 , a breaking point was reached when two youth ministers left their posts (Algrøy 2012a, 27; b, 17; Gilje 2012, 24; Hamre 2006). Towards the end of one of the interviews, one respondent shared a brief description of prophecies connected to the crisis in 2006, when "horrible prophecies" were given to people who had been singled out as traitors to the former senior pastor. "That stuff was immensely harsh," the respondent said.

As Living Word was a high profile church, internal conflict within it was sure to catch the media's attention. Christian and non-Christian newspapers and channels covered the unfolding events. A group of members, led by the church's head of missions, Olav Rønhovde, rallied with the ambition to change the course of events. A crisis of authority and leadership ensued, but no internal mechanism or apparatus existed for replacing the senior pastor. Pastors from other churches were later called upon to help, but to no avail. A schism unfolded. Flăten went on sick leave and a new team of leaders gained control of the church, working to alter the organization's structure, implementing a set of statutes, and establishing a general assembly. Recounting the schism, one of my respondents emphasized the importance of new leaders who, guided by mentors from other churches, "[said] straight that the way in which things had been done was wrong." The mentors were founder and former senior pastor Åge Åleskjær of the Oslo Christian Center and Robert Ekh, former pastor of Word of Life at Uppsala. They found the church's forms of prophecy to be disturbing, in addition to other issues that were made public around the time Flăten left his post (Åleskjær and Ekh 2006).

Rønhovde was elected temporary pastor at first, and made permanent senior pastor in 2008, which was also the year when the church's secondary school was closed as a result of a decrease in numbers of students signing up. In 2009, "Living Word" was renamed "Credo Church." Since then, black italicized letters spelling "Credokirken" have made up the church's logo, which is displayed at the most conspicuous top corner of the church's large, brown building at Kråkenes, south of Bergen. ${ }^{3}$ By 2012, 55 percent - around 1400 — of the church members had left, some 1000 of whom seem to have abandoned church activity altogether (Selbekk 2012). When journalists from the Christian newspaper "The Day" (Dagen) contacted former members, it was reported that many declined requests for stories and testimonies, describing the events as still 
too painful to discuss (Gjestad 2013,6). Years passed and the controversy died down, but was not entirely forgotten.

As illustrated, Flåten received and transmitted messages perceived to be from God, a practice clothed in the language of prophecy-for better or for worse. Understood as the gift of prophecy, the descriptions fit Weberian charisma well, as attributed to a person thought to possess "a certain quality of an individual personality by virtue of which he is set apart from ordinary men," on the basis of which Flăten was "treated as a leader" (Weber 1947, 358). Later, however, when authority met with opposition, prophecy was transformed into a tool for maintaining control. Prophecy acquired a dark side, a reminder of Weber's point that charisma is socially constructed and "what is alone important is how the individual is actually regarded by those subject to charismatic authority, by his "followers" (Weber 1947, 359; cf. Bensman and Givant 1975, 571; Wallis 1982, 26). Moving forward, processes of transforming charisma-and prophecywould become key to re-establishing interpersonal bonds and authority structures within the congregation.

\section{Transforming Foundations of Authority}

Recent statistics reveal that the Credo Church has 1081 registered members, a few dozen fewer than in 2012 (Department of Culture 2017). Senior pastor Olav Rønhovde and the Credo Church rarely feature in the media, and in an interview from 2012, Rønhovde described the church as having become more relaxed (Almelid 2012a). In the same article, a married couple stated that one main difference between Living Word and the Credo Church is the latter's stronger emphasis on fellowship and relationships, as opposed to members becoming tied to the pastor: "Today, people can say what they feel and think. It's a constant, ongoing process, and that is essential" (Almelid 2012a, 37). In a more recent interview, Rønhovde stated that the congregation's drive has been rekindled (Gilje 2016). The church runs a Christian primary school, and reportedly hosts on average 300 attendees on Sundays, 60-70 young people at Friday youth services, a couple of hundred women at women's meetings. In addition the "Substance" Bible college (Substans) has 44 students and is run in collaboration with two local Pentecostal congregations (Gilje 2016).

In the beginning of this chapter, Matthew pointed out style of leadership as one of the defining differences between the Credo Church and 
Living Word. Asking Matthew how pastor Rønhovde had been elected, Matthew explained that he was originally employed as a missionary and teacher at the Bible college. Matthew was himself present at the meeting where Rønhovde was elected senior pastor:

He heard from God that God wanted to use him as pastor. He told us at a service when we were about to elect a new [pastor] [...] He asked if we accepted him as pastor and we would vote for or against. Almost everyone [voted] in favor [...] You wrote "yes" or "no" or "blank" on a note. "No" and "blank" comprised maybe around ten percent of the total votes, not much more. The "yes" was almost unison.

We learn three things from Matthew: first, that Rønhovde was already an established leader figure in the congregation. Second, that Rønhovde had "heard from God," and had shared this experience at a service prior to the election. While the initiative in this narrative is God's own, it should be noted that Rønhovde tells the story somewhat more cautiously, framing the task of becoming senior pastor as a vocation for which he had no particular desire (Almelid 2012a, 37). Third, his experience of God calling him to the post as senior pastor was not itself sufficient; the congregation's consent was sought in general assembly, which was given by means of a ballot. Rønhovde's election involved elements of charisma that are not entirely divorced from prophecy, but also involved the new rational aspect of a ballot in general assembly. Combined, these elements constitute the routinization of charisma in the Credo Church, not by replacing charismatic authority outright, but by introducing new elements to the mix.

Matthew continued to stress that "[ the senior pastor] must be able to hear from God. He must be able to bring messages he receives from God to the church in such a way that you understand what he's saying." $\mathrm{He}$ connected the ability to receive messages from God to a leadership model that is often called the fivefold ministry, based on Ephesians 4: 11-12, which includes evangelist, teacher, pastor, prophet, and apostle. I asked Matthew whether he would call the pastor a prophet. He responded that he may be used as one, but pointed out that "[it's] not his primary function." Rather, he explained, the senior pastor bears the main responsibility for the church; he "carries the whole church on his shoulders-for better or worse. It can [involve] spiritual battles too [...] He has spiritual, but also practical and financial advisors, [but] he has the heaviest load with regards to decisions, both financially and spiritually." Matthew was also careful to 
point out that, while there are ups and downs to being a senior pastor, he has no "fringe benefits like [he might] in a company": the responsibility will gain him a greater reward from God, but also a stricter judgment.

Whereas the position of senior pastor used to have numerous benefits, it is now framed in terms of responsibility, involving heavy demands and difficult decisions. Paula was also sensitive to the burden that comes with leadership. She explained that when somebody is doing God's work, they should not be in that position for too long. She saw change as something healthy, not only to the church, but also to the person in the position of responsibility: "You shouldn't build something strongly around your own person, but be allowed to grow into new things," she said, indicating that the vocation needs not be permanent.

Per Ove Berg, who is pastor at the Credo Church along with Rønhovde, and who consented to being referred to by name, elaborated on the possibility of the senior pastor terminating his ministry. Quoting and elaborating on the statutes, he provided a normative perspective on the issue. The senior pastor can step down if he so wishes, in agreement with the management team and the board, who also suggest his successor to the church. Reading from the statutes, and commenting upon them as he went, Berg explained that a senior pastor may be removed if he engages in "inappropriate conduct incompatible with the ethic and moral norms of God's Word: such as immorality, financial default, heresy [...] or if the senior pastor in other ways neglects or abuses his ministry, the other [members of the] management team and the board together will consider termination of the position." In other words, a legal-rational aspect has been added to the legitimacy of the senior pastor's authority, namely a set of statutes to which he is accountable. The senior pastor's position then, depends on a collection of elements: a vocation from God, his personal capability, the congregation's confidence, and conformity with the church's statutes. The introduction of these aspects is also reflected in the procedures established for electing a new pastor, in which case, the statutes demand that the board makes a suggestion for a new senior pastor to the congregation in general assembly. A two-thirds majority is required from the members present. Berg explained that all adult church members have the right to vote at general assemblies and that the gatherings, ordinarily held once a year, decide the contents of the statutes, to which "everyone, including the senior pastor, every organ is subordinate $[\ldots]$ No one can go and change that." 
Berg also explained how a vocation is discovered and how to proceed if, for example, several individuals were to perceive themselves as called by God to be the new senior pastor:

There is a dynamic between the first [criterion], that God is calling [the person], which is recognized through the second [criterion]: the people, who give trust, who experience the person in question as worthy of our trust; that the person has a gift $[\ldots]$ and a personal demeanor that qualifies him for the job. Thus viewed, human beings elect [the pastor]. You can only be a leader based on trust. Everything is built on trust. Everything is built on free will $[\ldots]$ The dynamic is such that the person in question, naturally, must have faith and be convinced that this is right, that this is what he is supposed to do. There may also be formal qualifications, but that is not always so.

It appears that the election process contains elements of democratic process mixed with personal conviction. One could argue that there is a certain tension in this dynamic: on the one hand, there are the congregants, who may have a favorite candidate. On the other, there is always the question of whether one has interpreted God's will correctly-especially, one might imagine, on the part of the newly elected leader. However, Berg's explanation brings the two into line.

To Matthew, it was important not to forget that "a pastor, whether he leads one hundred or ten thousand, should ideally be chosen by God: [I]f Rønhovde were to quit as pastor [or] died [...we] must ask God: 'Who do you want as a new pastor?' It comes down to asking him: 'What do you want?'” I asked Matthew how one would find out what God wanted: "You'd have to seek God and let God answer. You need some time, really, because God is sometimes slow on the trigger. $\mathrm{He}$ likes to test us, [to see] if we're serious. If you seek God, you have to wait until he responds."

In the Credo Church, leadership is also shared. There is a senior pastor, who "hears from God," as well as people with different areas of responsibility, including the board and management team, spiritual and economic advisors, cell group coordinators, missionaries, and youth ministers. The respondents seemed to appreciate these more formalized leadership structures. At the same time, in reference to leadership more generally, another respondent, Mark, emphasized the initiative of up-and-coming leaders. "It happens naturally," he explained, and continued: 
You see people who branch out, who have the interest needed and who work at it. I guess a lot of it [happens in the way that] people who take responsibility receive responsibility. It's voluntary and people rarely do it for the sake of their own gain. It's because they have the heart for it and take initiative.

I asked him to elaborate. Responding, he immediately connected the question to Living Word's leadership structure: "With regards to the pastor being fired by the church without the involvement of an elder council-no such thing existed at the time." The question, then, was who had the authority to ask the pastor to leave. He stated that the authority to depose a leader "rests with the church."

Along with the transformation of leadership structures came new understandings and practices, particularly involving gifts and manifestations. For example, prophecy is still an important gift of grace. Respondents varied in their perceptions of these changes. While Paula's view was largely positive, she was not altogether dismissive of the old ways: "In the beginning, a lot of people experienced that the pastor or other leaders received prophecies that changed people's lives," she stated, expressing a sense of nostalgia for the way prophecy had been practiced at Living Word. "There was a lot of prophecy, which I experienced," she said reminiscing, "where the pastor walks around and receives messages from God. There was a lot that was not from God, but also a lot that was from God." There is a sense of ambivalence to Paula's words: she distinguishes between true and false prophecies, emphasizing the helpfulness of the former, while also expressing reservations.

When prophecy at Living Word turned into a means for public rejection of and creating a social stigma for dissenters, what followed can be viewed through the lens of Weber's description of how a leader's charisma is likely to disappear if "he is for long unsuccessful." We have learned that prophecy was important to constructing and maintaining charismatic authority at Living Word. However, the particular way in which prophecy was applied seems to have changed over time, as it went from providing reassurance to carrying exclusion and social stigma. It seems that the shift in how prophecy was enacted robbed it of its capacity for generating charisma for the senior pastor; what had previously been a source of trust was tainted through its employment to discourage dissent. From a Weberian perspective, such a reaction to delinquency is to be expected from a charismatic leader (Weber 1947, 359). It is more noteworthy that a gift of 
grace that had initially been so important for establishing charismatic authority itself seems to have become corrupted, causing not only the charismatic authority it had served to support to consequently crumble, but also the very status of prophecy itself. This is coherent with the prevailing interpretation of Weberian charisma being solely in the eye of the beholder(s), as quoted earlier. In the words of David Setley and Douglas Gautsch, charisma is "based solely on the evaluation of the follower on a leader's traits, not on any absolutes or skills the leader actually has" (Setley and Gautsch 2015, 23-24). While this study's findings are consistent with that interpretation, they also show how abuse of a charisma-generating practice can turn against itself. Such an interpretation of transformations and the respondents' views on prophecy is also helpful for an understanding of how the congregation acquired a cautionary approach to prophecy. From this angle, it follows that transforming the foundations of authority was a necessary step in order to rebuild trust in the emerging leadership, as well as in wider fellowship within the church.

So far, we have seen that these transformations entailed a process of rationalization in favor of which "the purely personal character of leadership is eliminated" (Weber 1947, 364, italics added). The keyword here is purely; it is significant that the charismatic element of authority has not been replaced. Rather, it seems to have been toned down, while legalrational elements have been added as mechanisms for guarding against the abuse that may come with a purely charismatic leadership. The language of prophecy is conspicuously absent in illustrating the reconstructed charismatic element of authority, which could mean that charisma itself has been transformed. Its previous conditions for authenticity have been replaced by new ones. Such a revamp of conditions for authority also bears on questions of authenticity, detectable in relation to other gifts and manifestations, among them "falling in the Spirit."

\section{Falling in the Spirit and the Problem of Authenticity}

Falling in the Spirit is often considered a hallmark of Charismatic Christianity (Inbody 2015, 7), and was widespread within the Faith Movement. Living Word was no exception. Berg was careful to point out that falling in the Spirit is not something that it is possible to "practice" as such, and connected a description of falling in the Spirit to a question of authenticity: 
At certain times and under certain circumstances, God's power has manifested in such a way that, upon encountering it, there is a physical reaction: you fall easily, because it is a real encounter with the power of God. But the point is not falling in the Spirit. The point is that human beings have needs and God wants to meet those needs, whether it be healing or other things. And that is not something that you could construct, though there may be some who have tried, [maintaining] that "this is proof that God is doing something" - that people fall in the Spirit. It's not any kind of proof at all; it is a physical reaction-a phenomenon, but it isn't something that you could construct.

Berg's response contains a rationalistic explanation of the purpose of, and reason for occurrences of "falling in the Spirit": It is a physical reaction, a natural consequence of encounters between human beings and the power of God. Berg finds objectionable, however, the implication of human agency and involvement that, in his view, is neither wanted nor warranted. $\mathrm{He}$ is concerned that this is detrimental to an authentic experience as opposed to one that is "constructed." Berg connects falling in the Spirit to an understanding of God as nurturer, expressed in the normative statement that falling in the Spirit is not supposed to be an end unto itself. Rather, it is a way in which God gets involved in people's emotional lives. He further objects to the perceived notion that physical reactions to God's presence are proof of God's activity, yet remain a way in which God meets human needs. Berg's response, then, serves as an entry point to unraveling the rich complexity concealed in the phenomena of gifts of grace and manifestations of the Spirit.

Considering the contexts in which falling in the Spirit is commonly observed, I was also curious as to whether Berg considered any specific social or ritual conditions to be associated with the phenomenon. Asking whether it might be possible to facilitate such events, he responded: "Yes, perhaps you could. You can tell that maybe it happens more often at some types of services than at others, but to us: if it happens, it happens." $\mathrm{He}$ further explained that falling in the Spirit also occurs outside the practices of laying on of hands or intercession, "but it is often connected to it-for some reason or other." In cases where falling in the Spirit occurs frequently over a period of time, however, "it is very easy to start imitating, that you are going to 'pull this off,' and then you give a little push." Berg expressed that encouraging people to fall in this manner amounts to a human factor entering the picture in a way that is "not good." He particularly expresses 
reservations that, when falling in the Spirit happens frequently, people become socially conditioned to expect its occurrence. This, in turn, creates social pressures that can lead to interference whereby the phenomenon is, quite literally, pushed to occur. On the one hand, we may note an acknowledgment of a frequent connection to tactile human mediation, a practice whereby a pastor or intercessor lays hands on a person, often connected to falling in the Spirit. On the other hand, Berg rejects the idea that the two are linked by necessity; human mediation is not necessary, and falling in the Spirit may take place without it. Given Berg's reservations, it appears that a concern for authenticity is central to the new official position of the church.

Interestingly, Berg also connected authenticity to geographical location and culturally conditioned interpretation of the phenomenon. Having worked in Brazil as a missionary for several years, he recounts how falling in the Spirit was associated with "evil spiritual powers manifesting in encounters with God's power and the name of Jesus." People did not fall in the Spirit outside these particular situations, he pointed out. Despite these reservations, there are some ways in which the congregation may facilitate falling in the Spirit by being prepared just in case someone does fall. However, it is neither expected nor explicitly encouraged; this preparation is meant to create a "safe place" so as to prevent people from incurring injuries (see also Poloma 1997, 264).

Berg attributes the authenticity of falling in the Spirit to God's agency, and its dependence upon the human subject's passivity. From this perspective, any human involvement would undermine the authenticity of the experience, and consequently, the expression itself. However, as illustrated by the example from Brazil, the interpretation of falling in the Spirit is subject to cultural conditions quite apart from the question of authenticity. These nuances and reservations are important to keep in mind with regard to the reflections of respondents from among the ordinary members.

During an interview with Matthew, an insider discussion of authenticity intertwined with the topics of apologetics and personal reflections on differences between Living Word and the Credo Church. This was illustrated in a story he shared of a conversation with a presumably nonCharismatic Lutheran in which Matthew objected to the postulation of human interference-particularly physical touch: 
I met a Lutheran on the street and he was on his way out to evangelize. We started talking and when I started telling [him] about physical stuff, he was so negative. I told him that I had been prayed for by some Americans. They gathered around me in a circle. Nobody touched me. They breathed on me. I fell straight down, as if the floor vanished. I noticed that this stopped one of [the Lutheran's] main arguments. He thought I was talking about pushing, but they didn't touch me. I just fell straight down. I also had [...] other experiences. Once, [when] somebody was talking to me, or laid hands on me, I knew that there was a guy behind me. I fell backwards, but didn't hit him. [...] When people breathe on me and I fall because they breathe on me, there must be a reason for it - that there is a power. That must be it. So you could ask, what power was it: God or something else?

Matthew's response involves legitimizing authenticity by rejecting the involvement of human touch. Well aware of the Lutheran's skepticism, and his suspicion that Matthew had been pushed to fall by his intercessors, we note the same objection to the necessity of human touch as expressed by Berg. The absence of touch in this case was used as an argument for authenticity. Nevertheless, Matthew situates his experience in a social context.

As Matthew elaborates on the event, he increasingly conveys his conviction that the experience of falling may indeed have been an effect of encountering God. He is rather cautious in doing so, however, and reveals doubt intermingled with his conviction. Interested in when these events had taken place, I asked whether they had occurred at Living Word or the Credo Church. He stated that, "falling backwards without hitting [the man behind me] was at Living Word, and that [episode] where people breathed on me was either at the Credo Church or at Living Word. So I've had a couple of powerful experiences, but none of them took place recently." At the Credo Church, Matthew reported, "it happens that people come forward and are prayed for, but not many fall to the ground. Whether that was mostly [people's] imagination, I don't know. It hasn't happened lately, except in a couple of cases $[\ldots]$ Some just sway. Others collapse before anyone touches them, and some fall when somebody touches them lightly." It is interesting to note that falling may be less frequent at the Credo Church than at Living Word, but Matthew's openness is also striking in that he includes a critical perspective with regards to the authenticity of falling. Despite having had several such experiences, and defending them in a conversation with a nonCharismatic, Matthew remains open to the possibility that such events are merely imagined or constructed. 
Mark also expressed a critical perspective, this time linked to what he perceived to be a lack of correlation between gifts and manifestations on the one hand, and a Christian lifestyle on the other. Part of this perspective was linked to how manifestations were enacted at Living Word.

Mark: There has been some criticism. People who only come to Sunday services and fall to the ground, and then they live completely uncritically towards their own life and well-being during the week, not paying consideration to themselves or others in everyday life-that's not very fruitful. At the same time, I think a lot of people are strengthened by that experience.

Jane: $\quad$ Manifestation experiences didn't always lead people to ...

Mark: No, not always. Some [people] liked the experience, but they didn't always bother to work on themselves sufficiently to change [their] lifestyle. Hopefully, that's the exception and most people let an experience like that strengthen them in everyday life [so that] they make changes to do what they feel is right and what they feel they are created [for] and motivated [to do].

Mark considers falling as a way to receive strength, but whether falling is sought for its own sake, or whether that strength is mobilized to transforms one's life, is up to the practitioner. Whatever he or she decides seems to have no bearing on the question of authenticity; what is at stake is how the authentic experience is used. To Mark, manifestations of the Spirit are supposed to have consequences for one's lifestyle, which he sees as having become more central to the Credo Church's teaching: "Reason may have gained a bigger place. We consciously build our lives for good values in society, development and not least family-how we want to live our lives." This suggests that the focus of manifestations has shifted from seeking manifestations to seeking life transformation by means of them.

\section{Gifts of Grace and Words of KnOwledge}

In addition to shifting the focus from seeking gifts and manifestations, the reconstruction of the congregation has also brought about adjustments to how they are enacted. One gift that has gained prominence is Words of Knowledge, as illustrated by Paula's description: 
I also think it has become more like you can share words at the servicesWords of Knowledge. We have one [person] who experiences that a lot, for example when somebody has a painful knee. Then he is allowed to pray for them. He gets a chance to [do so].

Paula's impression was that of an increased openness for people to share Words of Knowledge, which she reports as especially frequent with one congregant. Previously, the senior pastor was in charge of the service, and acted as mediator of the messages given. Today, Words of Knowledge are enacted by ordinary congregants, who are allowed to proclaim them at the discretion of the pastors. We may appreciate that Paula does not refer to current pastors as being involved in giving Words of Knowledge, although they maintain control of their enactment. This was also congruent with my observations at Sunday services, where one congregant came forward during a post-service intercession meeting and shared a Word of Knowledge through the microphone. I asked Paula whether practicing gifts of grace is now more evenly spread throughout the congregation. "Yes," she responded, "[but] during the services, not a lot of people are given the chance [to practice] gifts of grace at the moment." Paula also expressed regret that gifts of grace were not used more frequently at the church, but also added that they are practiced in small groups, which constitute "places for training and trying out the gifts of grace in safe environments. It's not easy," she said, explaining that the gifts are related to each individual's walk with God and the processes of maturing one's personal faith. Walking up to stand in front of several hundred people, proclaiming to have a message from God, can be a terrifying affair. "It is something that requires trust. You need to have the nerve for it and have a yearning for it," Paula elaborated. From her description, we understand that enacting gifts of grace puts a person in a vulnerable position. The need for training becomes clearer if we understand the element of self-doubt involved, an example for which we will find in one of Matthew's experiences.

Matthew was reminded of Words of Knowledge when discussing prophecy. The former is a gift thought to bring mental and bodily challenges to light, "that somebody is struggling with [certain] thoughts," and physical ills, such as "somebody having a painful shoulder." Matthew stated that God can provide comfort through Words of Knowledge which, he said, "happens sometimes" at the Credo Church. Words of Knowledge can be enacted in two ways, he explained: Either the message is given straight to the receiving person, or they can come forward for intercession. However, he also included 
the caveat that Words of Knowledge "can be too revealing," suggesting that this gift needs to be practiced with caution and consideration for the vulnerability of the receiving person. Matthew reported an experience that would fit the description of either prophecy or Word of Knowledge, although he refrained from using either of those terms:

God said to me once, "Go over to [that guy] and tell him that he will become a Christian tonight." I went back and forth a little [but] eventually did it. Never before had I imagined that I would say something like that to someone. He wasn't a Christian, but he did become a Christian that evening. On the other hand, you could call it manipulation; I thought that I wanted to know whether the power is God or something else.

Matthew related this story in the context of having experienced an allknowing power. Yet, doubt resulting from the inclusion of a critical perspective is part of Matthew's description, both of what happened during and after the event. First, he went "back and forth," before finally making the decision to carry out the perceived command, and second, he stated the possibility that the experience was a form of manipulation. Either way, the question of authenticity is at the very heart of Matthew's quest for confirmation of God's existence. In the end, it appears as if Matthew's curiosity over whether the message had really been from God or not led him to act. That the man actually became a Christian that evening gave Matthew reassurance that his interpretation was correct, but he hesitates to rule out his doubts completely.

A theme of vulnerability seems to permeate the respondents' reflections on practicing gifts of grace, as well as references to ritual restrictions placed upon their enactment, but also upon the language enveloping their enactment. Interestingly, experiences at Living Word, where the senior pastor transmitted messages from God, were labeled prophecy with apparent ease. By contrast, such practices now appear to be referred to as Words of Knowledge or not labeled "gifts of grace" at all. Reportedly, they are now more evenly distributed among the congregants rather than centered on the senior pastor, and invite critical perspectives rather than command obedience. It appears as if Weberian charisma has been redistributed and democratized, but this charisma also seems to inspire consciousness of one's own and others' vulnerability, as well as questions regarding authenticity. As indicated by Paula, another change can be seen in the decreased frequency of enacting gifts related to transmitting messages from God; this appears to reflect a wider trend, to which we now turn. 


\section{Frequency of Gifts and Manifestations}

Mark notes that, compared to Living Word, "there is probably some difference" in how gifts and manifestations are practiced at the Credo Church. According to him, manifestations of the Spirit have "almost disappeared" there. Still, he emphasizes that members are not intimidated by manifestations when they do occur. Outsiders, however, may find manifestations of the Spirit to be a frightening experience. Mark adds that "services are much shorter now than they used to be":

Jane: Right, because they used to last for three hours?

Mark: Yes, it's only because of grace that people can sit [there] for that long-it's got to be something special [laughs]. Maybe it's [something that] comes in waves. It may well come back. I don't know.

Jokingly referring to the patience needed to endure three-hour services as a bit of a miracle, Mark also suggests the possibility of a cyclical waxing and waning of gifts and manifestations according to "waves." $\mathrm{He}$ also seems comfortable with the contemporary lower frequency of such events. "Do you miss anything from the old way of doing things?" I asked him:

I don't know it all that well, but not really, because, especially regarding employment of gifts of grace and speaking in tongues during services-there is little culture for that here [in Norway] and it is seen as very strange [...] to people who are not used to going to church. So it can almost work against its purpose. When Paul teaches on [the subject], he says that [speaking in tongues] is for one's own composition, and not so much for use during services, or when [people] gather. That can be [a] positive [thing], making it easier to bring people along. So they don't just think, "Dear me, this right here ... If this is how you become when you become a Christian, that's freaky."

Mark gives several reasons why he considers a lower frequency to be a good thing: he considers it more in line with Pauline teaching, to attract less stigma, and to be less alienating to Norwegians and, consequently, more beneficial to mission activity. Matthew shared Mark's view on glossolalia at services: "If a non-Christian enters a church and everybody just jabbers on in tongues," explained Matthew, "the non-Christian would think: 'They've gone completely crazy!'” He elaborated a little further, stating that when glossolalia takes place in the presence of non-Christians, the point of practicing the gift must be the interpretation of the message: 
It is written [in the Bible] that if nobody can interpret, you should remain silent. There is supposed to be a maximum of three people [who speak in tongues] and it should be done systematically, and in order, so people can understand it. Apart from that, speaking in tongues is for private use. It says in different [Bible] passages that speaking in tongues is [to be kept] within; nobody [else] would understand what's going on. If the Spirit isn't in on it, you may ask if you could just laugh at the whole thing.

Like Mark, Matthew believed that glossolalia might alienate people who are unaccustomed to the phenomenon. Both frame their responses in a way that includes humor and self-deprecating humor, not just on their own behalf, but that of Charismatics in general. Obviously, they are quite aware that non-Christians and non-Charismatics may find glossolalia intimidating, and that this might possibly prevent new visitors from returning.

Not all congregants share this outlook. Asking Paula whether she misses anything from the Living Word era, she responded:

You see with all congregations that they go through various phases. There may be times when there's a lot of speaking in tongues, you intercede for the sick at every service, invite [people] to come forward for salvation at every service, and when people receive intercession, they'll often lay strewn about because they fell in the Holy Spirit. After that came the laughter movement. There have been different trends.

Paula explained that she had experienced holy laughter herself, and described it as something that brought freedom to people. It is clear, however, that she considers various forms and frequencies of manifestations to be temporary: trends come and go. Paula described their enactment as more restricted at the Credo Church than at Living Word. "I [sometimes] miss that here now-that freedom at the services and that the Holy Spirit is allowed to work," she said, before adding that,

I suppose it has also been important to build on the Word of God and that the preaching gets a healthy balance. [...] You get the foundation on the Word of God. Churches that only build on manifestations, glossolalia, and prophecies won't have that foundation on the Word of God. It just becomes vague/airy [spevende] and may ultimately fall apart, which is what we've seen [happen] here.

Despite her missing the freedom at Living Word, Paula's opinion on the current practice is somewhat mixed. Restricting the use of gifts has coin- 
cided with a stronger emphasis on the Bible, which she considers to be healthy and necessary. She interprets the collapse of Living Word as being attributable to several factors, one of them being its exclusive focus on gifts and manifestations without a foundation rooted in Biblecentered teaching. While valuing gifts and manifestations, the respondents also consider them to be potentially harmful, although in different ways. We may note the emergence of a view whereby such practices are a mixed blessing; there are benefits, but potential harm must also be taken into account.

At Living Word, gifts and manifestations used to be centered in the senior pastor, contributing to the generation of the charisma needed to support his authority. As the flow of these processes collapsed, charismatic authority crumbled, while also affecting views of and ways in which gifts and manifestations were practiced. As part of the reconstruction process, the new leaders ceased to regard them as ways of legitimizing leadership authority. This has entailed two transformations: On the one hand, the present view of gifts and manifestations has become tainted, which reinforces an ambivalence that has parallels to late modern radical doubt as discussed in Jessica Moberg's dissertation (2013, 111). On the other hand, thinking with Weber, this is part of the institutionalization of leadership legitimacy in terms of democratization. In addition to a decreased frequency, the enactment of gifts and manifestations has partially been relocated from front and center stage at Sunday services to more secluded settings such as cell groups and individual practice.

The Credo Church, it appears, has introduced elements of rationalization. However, concerns that fuel routinization in this congregation go beyond issues of institutionalization; they heed questions of authenticity as well as hedge personal vulnerability, thus partially relocating the enactment of gifts and manifestations from Sunday services to small groups.

\section{Conclusion}

This chapter has investigated two transformations in the Credo Church, the institutionalization of Weberian charisma on the one hand, and of enacting charismata — gifts and manifestations of the Spirit—on the other. Particular attention has been paid to prophecy, falling in the Spirit, and similar practices. From a Weberian perspective, charismatic authority can be said to have routinized by way of adding elements associated with rational authority. The transformation goes deeper than that, however; the very 
mechanisms by which Weberian charisma is generated have been altered because the enaction of prophecy, a primary source of charisma at Living Word, was corrupted. As such, the enaction of prophecy has itself lost some of its capacity for generating the charisma needed for upholding an exclusively charismatic form of authority. It does not, however, appear to be the case that receiving and transmitting messages from God has gone out of fashion. Rather, it has been transformed in terms of designation and distribution; the language of prophecy seems to have been replaced by a language predominated by Words of Knowledge. Communicating Words of Knowledge at the Credo Church is more widely distributed among congregants than prophecy has been, but is also subject to restrictions by the leadership. Those restrictions are not limited to the ways in which messages from God can be communicated, however, but apply to the enaction of gifts and manifestations more generally. The respondents rationalize these differences in terms of phases that "all congregations" go through; gifts and manifestations are more prevalent in some phases than others.

Respondents signal caution towards gifts and manifestations by expressing second thoughts concerning whether and to what extent God is involved in producing them, as well as their helpfulness in converting new Christians. Personal experiences, however, seem to have retained their significance in the respondents' religious lives. Furthermore, there is a strong emphasis on protecting the vulnerability of those involved.

\section{Notes}

1. Bibelen: Guds Ord was first published by Bibelforlaget in 1997 and has become a favorite among Norwegian Charismatics (Walstad 2010).

2. Living Word's broadcast was terminated along with "The Family Channel" (Familiekanalen) in April 2004, reportedly due to its poor transmission quality. The decision met with some protest from Christian communities (Aalberg 2004). The church was offered a deal with the recently launched 2003 national Christian channel "Vision Norway" (Visjon Norge). Living Word's television broadcasts were eventually discontinued in 2007 (Algrøy 2012b, 16).

3. The logo it replaced was comprised of a stylized globe, a sword, an open Bible with a flame, and big black letters spelling "Living Word Bible Centre" (Levende Ord Bibelsenter), which strongly resembles Word of Life at Uppsala's logo.

4. The phrase "hear from God" is not prevalent in Anglophone Charismatic discourse, but is nevertheless familiar (Wallis 1982, 33). 


\section{REFERENCES}

Aalberg, Per Ole. 2004. Fastlåst for kristen-TV. http://www.dagen.no/Innenriks/ Fastl\%C3\%A5st_for_kristen-TV-30588. Accessed 27 Nov 2017.

Åleskjær, Åge and Robert Ekh. 2006. Situasjonen på Levende Ord i Bergen. Norge IDAG, June 20. http://www.idag.no/aktuelt-oppslag.php3? ID=10405. Accessed 18 July 2014.

Algrøy, Eivind. 2012a. Fortellingen om Levende Ord. Dagen, October 27.

—. 2012b. Over tusen 'meninghetsløse' etter Levende Ord. Dagen, October 27. Almelid, Johanna H. 2012a. Menigheten har senket skuldrene. Dagen, October 27. . 2012b. Tiden etter Levende Ord: Sorgen, spørsmålene og tvilen. Dagen, October 27.

Anderson, Allan. 2010. Varieties, Taxonomies, and Definitions. In Studying Global Pentecostalism: Theories and Methods, ed. Allan Anderson, Michael Bergunder, André Droogers, and Cornelis van der Laan, 13-29. Berkeley: University of California Press.

Anderson, Allan H. 2014. An Introduction to Pentecostalism: Global Charismatic Christianity. Cambridge: Cambridge University Press.

- 2015. The Anthropology of Global Pentecostalism and Evangelicalism. New York: New York University Press.

Bensman, Joseph, and Michael Givant. 1975. Charisma and Modernity: The Use and Abuse of a Concept. Social Research 42: 570-614.

Bibelen: Guds Ord. Trans. Norvald Yri, Ingulf Diesen, Leif Jacobsen, and Sigurd Grindheim. Nesbyen: Bibelforlaget, 1997.

Bryne, Jarle. 2007. Pastorer i trosbevegelsen: En studie av to norske pastorer sin autoritetsforståelse og rolleforståelse. MA dissertation, University of Agder

"Carl I. Hagen til angrep på islam." Aftenposten, July 13, 2004. http://www. aftenposten.no/norge/Carl-I-Hagen-til-angrep-pa-islam-498746b.html http://www.aftenposten.no/nyheter/iriks/Carl-I-Hagen-til-angrep-paislam-6310042.html. Accessed 4 Apr 2017

Chryssides, George D., and Margareth Z. Wilkins. 2006. A Reader in New Religious Movements. New York: Continuum.

Coleman, Simon. 2000. The Globalisation of Charismatic Christianity: Spreading the Gospel of Prosperity. Cambridge: Cambridge University Press.

Credokirken. 2014. Historikk. http://www.levendeord.no/index.php?n=80. Accessed 23 July 2014.

Department of Culture. 2017. Oversikt over antall tilskuddstellende medlemmer $i$ tros- og livssynssamfunn. https://www.regjeringen.no/no/tema/religion-oglivssyn/tros-og-livssynssamfunn/innsiktsartikler/antall-tilskuddsberettigedemedlemmer-i-/id631507/. Accessed 11 Feb 2016.

di Giacomo, Michael. 2009. Pentecostal and Charismatic Christianity in Canada: Its Origins, Development, and Distinct Culture. In Canadian Pentecostalism: Transition and Transformation, ed. Michael Wilkinson, 15-38. Montreal: McGill-Queen's University Press. 
Gilje, Tarjei. 2012. Jeg hadde ønsket å fortsette. Dagen, October 27.

- 2016. Ny giv ti år etter krisen. Dagen, February 6. http://www.dagen. no/dagensdebatt/kristenliv/kommentar/Ny-giv-ti-\%C3\%A5r-etterkrisen-303437. Accessed 10 Feb 2016.

Gjestad, Fred C. 2012. Over tusen personer 'menighetsløse' etter Levende Ord kollaps. Dagen, October 27. http://www.dagen.no/Kristenliv/Over_tusen_ personer_«menighetsløse»_etter_Levende_Ord-kollaps-55672. Accessed 21 Feb 2016.

- 2013. Metoderapport: 'Levende Ord-kollapsen.' In Levende ord-kollapsen: Velsignet helg: Bruddet som knekte troen, ed. Johanna H. Almelid, Eivind Algrøy, et al, ii-vi. http://www.skup.no/metoderapporter/2012/2012-4_Levende_ ord_kollapsen.pdf. Accessed 21 Feb 2016.

Hamre, Sigurd. 2005. Levende Ord mot Jens. NRK, July 6. http://www.nrk.no/ hordaland/levende-ord-mot-jens-1.206833. Accessed 10 Feb 2016.

_ 2006. Flåten anklages - styreleder går. NRK, June 21. http://www. nrk.no/hordaland/flaten-anklages---styreleder-gar-1.627429. Accessed 31 Aug 2014.

Hellesund, Dag. 2006. Overlater Levende Ord til brite. Bergensavisen, April 24. http://www.bt.no/nyheter/lokalt/Flaten-venn-trekker-seg-1806811.html. Accessed 9 Feb 2016.

Honningsøy, Kirsti H. 2011. Grotesk utsagn fra Hagen. NRK, August 14. http:// www.nrk.no/norge/_-grotesk-utsagn-fra-hagen-1.7749407. Accessed 9 Feb 2016.

Inbody, Joel. 2015. Sensing God: Bodily Manifestations and Their Interpretation in Pentecostal Rituals and Everyday Life. Sociology of Religion 76: 1-19.

Kanal 10 Norge. 2014. Enevald Flåten startet og ledet Norges største menighet i Bergen. Kristen TV $i$ Norge A/S. http://www.kanall0.no/aktuelt/2014/07/19/ enevald-flaten-startet-og-ledet-norges-storste-menighet-i-bergen. Accessed 30 Aug 2014.

Lie, Geir. 2011. Fra amerikansk hellighetsbevegelse til norsk karismatikk: Et historisk overblikk. Oslo: Akademia forlag.

Moberg, Jessica. 2013. Piety, Intimacy and Mobility: A Case Study of Charismatic Christianity in Present-Day Stockholm. PhD dissertstion, Södertörn University.

Newman, Barclay M., Jr. 1993. A Concise Greek-English Dictionary of the New Testament. Stuttgart: German Bible Society.

NRK. 2003. Brennpunkt: På barnetro skal landet bygges. Last modified November 25, 2003.http://www.nrk.no/nett-tv/klipp/23504/. Accessed 24 July 2014

Opheim, Birgit. 2012. Flåten melder Bergen-retur på Facebook. Dagen, October 24. http://www.dagen.no/Kristenliv/Fl\%C3\%A5ten_melder_Bergen-retur_p\%C3\%A5_ Facebook-55664. Accessed 10 Feb 2016.

Poloma, Margaret M. 1997. The 'Toronto Blessing': Charisma, Institutionalization, and Revival. Journal for the Scientific Study of Religion 36: 257-271.

Poloma, Margaret M., and Lynette F. Hoelter. 1998. The 'Toronto Blessing': A Holistic Model of Healing. Journal for the Scientific Study of Religion 37: 257-272. 
Robbins, Joel. 2004. The Globalization of Pentecostal and Charismatic Christianity. Annual Review of Anthropology 33: 117-143.

Selbekk, Vebjørn. 2012. Hvor er det blitt av dem? Dagen, October 27. http:// www.dagen.no/Leder/Hvor_har_det_blitt_av_dem-4278. Accessed 30 July 2014.

Setley, David M., and Douglas Gautsch. 2015. Leadership and the Church: The Impact of Shifting Leadership Constructs. International Journal of Business and Social Research 5: 15-25.

Singleton, Andrew. 2011. The Rise and Fall of the Pentecostals: The Role and Significance of the Body in Pentecostal Spirituality. Scripta Instituti Donneriani Aboensis 23: 381-399.

Skjoldli, Jane. 2014. Charismatic Controversies in the Jesus People, Calvary Chapel, and Vineyard Movements. In Controversial New Religions, ed. James R. Lewis and Jesper A. Petersen, 2nd ed., 81-100. New York: Oxford University Press.

Steinhovden, Tor Magne. 2006. 'Vi leker ikke menighet': Menigheten Levende ord: Visjoner fra Gud og ambisjoner for samfunnet. MA dissertation, University of Bergen.

Wallis, Roy. 1982. The Social Construction of Charisma. Social Compass 29: 25-39.

Walstad, Kristin. 2010. Populær bibeloversettelse full av feil. Forskning.no, December 30. http://forskning.no/kristendom-boker/2010/12/populaerbibeloversettelse-full-av-feil. Accessed 21 Feb 2016.

Weber, Max. 1947. The Theory of Social and Economic Organization. New York: The Free Press.

Wiederstrøm, Gunnar. 2006. Fylkesmannen reagerte på eksklusiv bilordning. Bergens Tidende, June 6. http://www.bt.no/nyheter/lokalt/Fylkesmannenreagerte-pa-eksklusiv-bilordning-1805161.html. Accessed 11 Feb 2016.

Yukl, Gary. 1999. An Evaluation of Conceptual Weaknesses in Transformational and Charismatic Leadership Theories. Leadership Quarterly 10: 285-305.

Open Access This chapter is distributed under the terms of the Creative Commons Attribution 4.0 International License (http://creativecommons.org/licenses/ by $/ 4.0 /$ ), which permits use, duplication, adaptation, distribution and reproduction in any medium or format, as long as you give appropriate credit to the original author(s) and the source, provide a link to the Creative Commons license and indicate if changes were made.

The images or other third party material in this chapter are included in the chapter's Creative Commons license, unless indicated otherwise in a credit line to the material. If material is not included in the chapter's Creative Commons license and your intended use is not permitted by statutory regulation or exceeds the permitted use, you will need to obtain permission directly from the copyright holder.

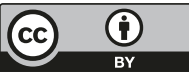

